$A B C D$ Arq Bras Cir Dig Letter to the Editor 2014;27(2):163-164

\section{ADENOCARCINOMA OF TRANSPOSED COLON: FIRST CASE OF SYNCHRONOUS TUMOR}

Adenocarcinoma de colon transposto: primeiro caso de tumor sincrônico

Rubens Antonio Aissar SALLUM, Gilton Marques FONSECA, Sergio SZACHNOWICZ, Francisco Carlos Bernal da Costa SEGURO, Ivan CECCONELLO

From the Departamento de Gastroenterologia, Disciplina de Cirurgia do Aparelho Digestivo, Faculdade de Medicina da Universidade de São Paulo (Department of Gastroenterology, Digestive Surgery Division, University of São Paulo School of Medicine), São Paulo, SP, Brazil.

\section{Correspondence:}

Gilton Marques Fonseca

Financial source: none
Conflicts of interest: none

E-mail: medgilton@yahoo.com.brReceived for publication: 24/01/2013 Accepted for publication: 18/12/2013

\section{INTRODUCTION}

The surgical and anatomical basis for using the colon as a substitute for the esophagus were established in 1911 by Kelling and Vuillet ${ }^{1}$ and for many years was the technique of choice for esophageal replacement ${ }^{2}$. Its use is helpful in benign diseases, such as caustic or peptic strictures, and malignancies ${ }^{1,3}$, especially when the stomach cannot be used, and also in children with congenital anomalies ${ }^{2,4}$. However, this procedure is subject to early complications, as ischemia of the colon and leakage ${ }^{5}$, or late problems as anastomosis stenosis, ischemic colitis, fistula due to diverticulitis and malignant lesions ${ }^{4}$.

The transposed colon cancer is a rare complication. Since 2007, six new cases were reported and two reviews published. Hwang et $\mathrm{al}^{6}$ found 10 reported cases of adenocarcinoma in the transposed colon and Bando et $\mathrm{al}^{7}$ also reviewed 10 cases in the literature, encompassing adenomas and adenocarcinomas.

The aim is to report an unique case of synchronous adenocarcinoma of the transposed colon.

\section{CASE REPORT}

Woman with 53-years-old diagnosed with congenital esophageal atresia, underwent to several surgical procedures in childhood, the latest was a cervical retrosternal esophagocoloplasty at 11 years old. After 42 years she was evolved with cervical dysphagia, and an initial diagnosis of stenosis of the esophagocolic anastomosis was performed, treated with endoscopic dilation without improvement. Later, biopsies were performed in the area of stenosis in proximal colonic segment (Figure 1) and polypectomy of sessile polyp of $10 \mathrm{~mm}, 5 \mathrm{~cm}$ distal to the stenosis (Figure 2). The pathological assessment showed tubular-villous intramucosal adenocarcinoma at the resected polyp and the area of stenosis was a invasive adenocarcinoma in colonic mucosa. Colonoscopy of remained colon was normal. Staging performed with CT scan showed an eccentric wall thickening of proximal colon transposed with luminal reduction target of left innominate vein; densification of mediastinal fat plane adjacent and regional lymph nodes up to $1.9 \mathrm{~cm}$.

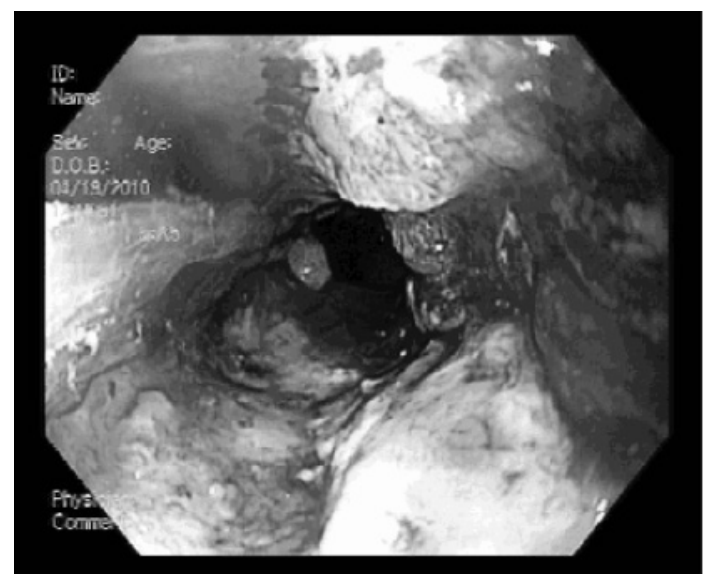

FIGURE 1 - Endoscopic view of the stenotic area in proximal colonic segment with advanced adenocarcinoma

Surgical treatment was performed with neck incision, sternotomy and laparotomy with resection of the colon transposed and a tactic transhiatal esophagectomy of the atresic esophagus in order to pull up the greater curvature gastric conduit obtained by the posterior mediastinum route. Resection of a portion of the left innominate vein which was invaded by the tumor was also performed. The pathological examination of surgical specimen showed moderately differentiated tubular adenocarcinoma invading pericolical tissues and the left innominate vein, with no affected lymph nodes - p T4 N0 (0 / 42) M0.

The patient developed postoperative superior vena cava syndrome, treated by anticoagulation. She had ischemia of the proximal portion of the stomach transposed being performed partial gastrectomy, and respiratory complications. She remained in intensive care and under multidisciplinary clinical support. Discharge of the hospital was after 128 days. Patient developed recurrent disease (lung metastases), started chemotherapy, and died nine months after surgery due to pneumonia.

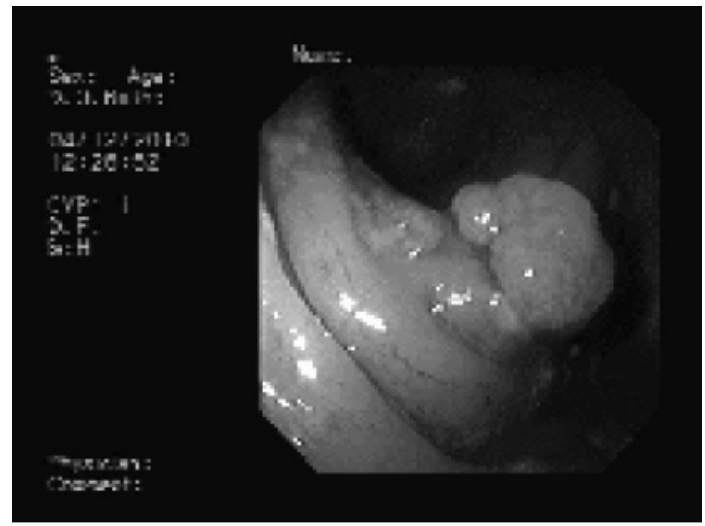

FIGURE 2 - Endoscopic view of the sessile polyp with sincronous intramucosal adenocarcinoma at the transposed colon more distal

\section{DISCUSSION}

There are basically three options for replacement after esophageal resection: stomach, colon and small bowel ${ }^{8}$. For many years, the colon was considered the organ of choice, but the stomach has been the most widely used in recent decades due facility of preparation of the gastric conduit and its more robust vascular supply as a result of a rich submucosal vascular layer ${ }^{9}$. Resection of the gastric lesser curvature allows elongation and a safe cervical anastomosis ${ }^{8,10,11}$.

In cases of previous gastrectomy, gastric caustic or peptic strictures, tumor involvement of the stomach or 
failed gastroplasty the colon is used ${ }^{9}$. Colonic interposition may have early complications as transposed colon ischemia and anastomotic fistula. Late complications as anastomotic stricture "redundant graft", ulceration, colitis, perforation, diverticulitis, or tumor in the colonic segment are reported ${ }^{4,5}$. Must be remembered that colorectal cancer has a high incidence; is the third leading cause of cancer diagnosed in men and second among women in the world ${ }^{12}$ and this colonic segment has a risk for malignancy too. There are 21 cases of adenoma/adenocarcinoma in transposed colon described in literature ${ }^{1,3-7}$.

This case shows that all patient underwent to esophagocoloplasty and develops dysphagia during late follow-up should be investigated for malignancy and the initial diagnosis of stenosis of the esophagocolic anastomosis without biopsy should be evoid.

\section{REFERENCES}

1. Liau CT, Hsueh S, Yeow KM. Primary adenocarcinoma arising in esophageal colon interposition: report of a case. Hepatogastroenterology 2004; 51(57): 748-9.

2. Klink CD, Binnebösel M, Schneider M, Ophoff K, Schumpelick V, Jansen M. Operative outcome of colon interposition in the treatment of esophageal cancer: a 20-year experience. Surgery 2010; 147(4): 491-6.

3. Licata AA, Fecanin $P$, Glowitz R. Metastatic adenocarcinoma from oesophageal colonic interposition. Lancet 1978; 311(8058): 285.

4. Altorjay A, Kiss J, Vörös A, Szanto I, Bohak A. Malignant tumor developed in colon-esophagus. Hepatogastroenterology 1995; 42(6): 797-9.

5. Houghton $A D$, Jourdan $M$, McColl I. Dukes A carcinoma after colonic interposition for oesophageal stricture. Gut 1989; 30(6): 880-1.

6. Hwang HJ, Song KH, Youn YH, Kwon JE, Kim H, Chung JB et al. A case of more abundant and dysplastic adenomas in the interposed colon than in the native colon. Yonsei Med J 2007; 48(6): 1075-8.

7. Bando H, Ikematsu H, Fu KI, Oono Y, Kojima T, Minashi K et al. A laterallyspreading tumor in a colonic interposition treated by endoscopic submucosal dissection. World J Gastroenterol 2010; 16(3): 392-4.

8. Davis PA, Law S, Wong J. Colonic interposition after esophagectomy for cancer. Arch Surg 2003; 138(3): 303-8.

9. Mine S, Udagawa H, Tsutsumi K, Kinoshita Y, Ueno M, Ehara Ket al. Colon interposition after esophagectomy with extended lymphadenectomy for esophageal cancer. Ann Thorac Surg 2009; 88(5): 1647-53.

10. Rizzetto C, DeMeester SR, Hagen JA, Peyre CG, Lipham JC, DeMeester TR. En bloc esophagectomy reduces local recurrence and improves survival compared with transhiatal resection after neoadjuvant therapy for esophageal adenocarcinoma. J Thorac Cardiovasc Surg 2008; 135(6): 1228-36.

11. Young MM, Deschamps C, Trastek VF, Allen MS, Miller DL, Schleck CD et al. Esophageal reconstruction for benign disease: early morbidity, mortality, and functional results. Ann Thorac Surg 2000; 70(5): 1651-5.

12. Jemal A, Bray F, Center MM, Ferlay J, Ward E, Forman D. Global cancer statistics. CA Cancer J Clin 2011; 61: 69-90.

\section{ABCDDV/1027}

\section{ABCD Arq Bras Cir Dig 2014;27(2):164-165}

\section{CARTA AO EDITOR}

\author{
Pedro Luiz Squilacci LEME
}

Ilmo. Sr. Prof. Dr.

Osvaldo Malafaia

Editor da Revista

Arquivos Brasileiros de Cirurgia Digestiva

omentando a Carta ao Editor escrita pelo professor Fabio Gonçalves Ferreira, de São Paulo: "A indexação da ABCD no PubMed e a cirurgia da hipertensão portal esquistossomótica no Brasil" (Arq Bras Cir Dig 2013;26(3):248-251)1, também gostaria de parabenizar o Corpo Editorial da Revista por sua recente promoção pelo índice Qualis, na área de Medicina III, quando esta foi elevada a B3.

Considero necessário parabenizar o Editor pela opção de publicar os artigos também na língua inglesa, aumentando consideravelmente o alcance e impacto da publicação, assim como pela presteza, pela forma desburocratizada e cordial de contato com o periódico e mesmo com o Editor. Para ilustrar a qualidade dos Revisores da Revista, informo que uma publicação recente da $A B C D$ : "Aspectos ultrassonográficos e anatomia da aponeurose do músculo transverso do abdome" (Arq Bras Cir Dig 2013;26(3):184-189)², recebeu o prêmio de melhor Pôster do 29th International Congress of the Medical Women's International Association, realizado em Seul, na Coréia, entre 31 de julho e 3 de agosto de 2013.

Ao avaliarmos os periódicos indexados disponíveis em nosso país, que aceitam artigos sobre Cirurgia Experimental, encontramos uma grande carência de opções. O Grupo de Pesquisa que represento tem artigos revisados pelo Conselho Editorial de periódicos que estão aguardando publicação por períodos próximos de dois anos.

A antiga Cirurgia Geral, nas últimas décadas do século passado, desenvolveu uma nova especialidade, a Cirurgia do Aparelho Digestivo, em função do aumento da complexidade dos procedimentos realizados sobre o Sistema Digestório, incluindo os transplantes de órgãos. Grandes Serviços de Cirurgia atualmente oferecem vagas para dois programas de Residência Médica, o de Cirurgia do Aparelho Digestivo e o de Cirurgia Geral Avançada, necessários pela complexidade das operações atuais, que dificultam a proficiência de um único cirurgião em operações tão específicas.

Durante o período da graduação em Medicina, a escolha da Especialidade Médica que cada estudante vai desenvolver durante sua vida profissional começa a se delinear, e os alunos precisam conhecer todas as especialidades básicas para enfrentar as provas de acesso à Residência Médica. A Cirurgia Experimental nesta fase se mostra uma ferramenta de ensino excelente quando desenvolvida como Programa de Iniciação Científica ou Extensão Universitária, auxiliando a Disciplina de Técnica Operatória e despertando o interesse pelo estudo de matérias básicas como a Fisiologia e avançadas como a Microcirurgia ${ }^{3}$. A pós-graduação, por sua vez, também leva especialistas de alto nível ao laboratório de pesquisa para o desenvolvimento das dissertações de Mestrado e teses de Doutorado. Apesar de todos estes fatores, os trabalhos experimentais têm um peso menor para as publicações, uma vez que são realizados com animais e seus dados são considerados inadequados para comparações com aspectos fisiopatológicos dos seres humanos, mesmo com os conceitos recentes de Medicina Translacional, que procura aperfeiçoar a inter-relação entre o conhecimento desenvolvido nos laboratórios das várias áreas das Ciências da Saúde com a prática médica.

Quanto à Revista $A B C D$, embora tenha foco específico em Cirurgia Digestiva como determinado por seu título, aceita artigos de Cirurgia Experimental, desde que sejam relativos a órgãos do Sistema Digestório4. Considero pertinente sugerir que em alguma reunião do Conselho Editorial da Revista seja proposta a ampliação desta permissão, uma vez que mais estudos poderiam ser divulgados por Revista tão conceituada. Avaliando o primeiro parágrafo das Instruções aos Autores da ABCD: “(...) tem por missão a publicação de artigos e estudos clínicos e experimentais que contribuam para o desenvolvimento da pesquisa, ensino e assistência na área da gastroenterologia cirúrgica, clínica, endoscópica e outras correlatas. (...)". Acredito não haver conflito de interesses nesta solicitação, uma vez que a Missão do periódico se configura bastante abrangente.

Recentemente tivemos a honra de manter correspondência por via eletrônica com o Editor da Revista $A B C D$ a respeito de um estudo relacionado à Cirurgia Experimental, desenvolvido por 